\title{
Modeling High Aswan Dam Reservoir Morphology Using Remote Sensing to Reduce Evaporation
}

\author{
Emad Elba, Dalia Farghaly, Brigitte Urban \\ Faculty of Sustainability Sciences, Institute of Ecology, Division of Landscape Change, \\ Leuphana University of Lüneburg, Lüneburg, Germany \\ Email: emad.e.elba@stud.leuphana.de
}

Received January 1, 2014; revised January 28, 2014; accepted February 16, 2014

Copyright (C) 2014 Emad Elba et al. This is an open access article distributed under the Creative Commons Attribution License, which permits unrestricted use, distribution, and reproduction in any medium, provided the original work is properly cited. In accordance of the Creative Commons Attribution License all Copyrights (c) 2014 are reserved for SCIRP and the owner of the intellectual property Emad Elba et al. All Copyright (C) 2014 are guarded by law and by SCIRP as a guardian.

\section{ABSTRACT}

Egypt is considered as an extremely arid country with annual rainfall under $200 \mathbf{~ m m}$ within coastal zones. High Aswan Dam Reservoir (HADR) experiences high evaporation losses of 15 BCM/year on average. Meanwhile, the water demand is increasing due to rapid population growth. Hence, measurements must be taken to decrease its evaporation losses. This can be achieved through controlling evaporation losses from the shallow lagoons, locally known as khors. The first step in the control process is to model the lake morphology using topographic data. Topographic maps are available for the time span before the construction of the High Aswan DAM (HAD), but they have not been updated. Hence, this study utilized satellite imagery since 1984 to develop a digital elevation model (DEM) that simulated the lake surface area. Correlated water levels were gained from the assembled hydrological database of HADR. This paper reports on the different alternatives for reducing the evaporation losses of two large khors, Kalabsha and El-Alaky, and two small khors, Korosko and Sara. It shows that the developed DEM allows estimation of the different hydrological features of HADR and its khors and recommends some measures to eliminate these khors to save up to 3 BCM by 2100 according to global climate model scenarios.

\section{KEYWORDS}

El-Alaky; Evaporation Losses; Kalabsha; Korosko; Lake Nasser; Morphology; Remote Sensing; GIS

\section{Introduction}

Egypt is an arid country. The rainfall does not exceed $200 \mathrm{~mm}$ annually within the costal zones, while it decreases rapidly inland to zero south of Cairo [1]. The main Egyptian water resource is the River Nile. Therefore, in 1959, Egypt began construction of the High Aswan Dam (HAD) on the Nile. This was $17 \mathrm{~km}$ south of Aswan, $900 \mathrm{~km}$ from Cairo, and formed one of the largest man-made lakes in Africa, called High Aswan Dam Reservoir HADR [2]. The Lake extends from the HAD north to the Cataract at Dal south. It runs from $21^{\circ} 02^{\prime} \mathrm{N}$ $30^{\circ} 37^{\prime} \mathrm{E}$ south to $23^{\circ} 58^{\prime} \mathrm{N}-32^{\circ} 55^{\prime} \mathrm{E}$ north for around $500 \mathrm{~km}$. It encompasses about $6500 \mathrm{~km}^{2}$ with a mean depth of $22 \mathrm{~m}$ corresponding to a water table of $182 \mathrm{~m}$ AMSL. Its volume is about $156 \mathrm{BCM}$ [3]. Its width ranges from 3 to $18 \mathrm{~km}$. In Egypt, where the lake is called Lake Nasser, it runs about $350 \mathrm{~km}$. In Sudan, where it is called Lake Nubia, it runs about $150 \mathrm{~km}$ [4]. The lake has about 100 khors with $12000 \mathrm{~km}$ of shore line covering about $3000 \mathrm{~km}^{2}$ (over $45 \%$ of lake surface area) as shown in Figure 1, which causes high evaporation losses [5]. This lake serves as long term storage for the Nile water during the flood seasons, to be used during subsequent dry seasons [6]. It is the main source of Egypt's fresh water. In 1969, the HAD was fully operational, saving Egypt from major floods and severe droughts [7].

Six meteorological raft and shore stations covering the whole lake monitor the lake meteorologically, as shown in Figure 1. These stations measure the water and air temperature, wind speed and direction, relative humidity, and barometric (atmospheric) pressure in addition to net radiation in some stations. They also estimate the daily 


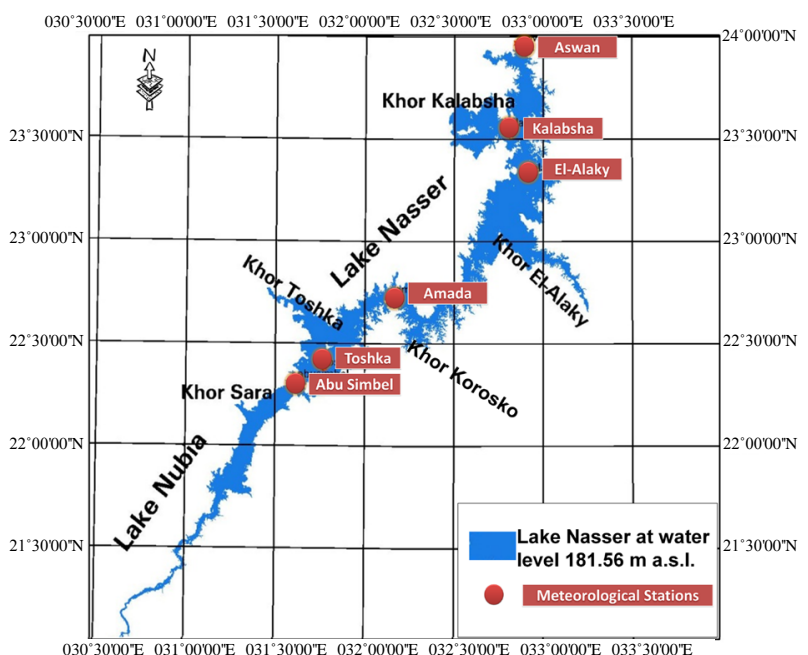

Figure 1. HADR at water level $181.56 \mathrm{~m}$ AMSL, major khors and location of the meteorological stations.

evaporation losses using these parameters. Aswan station has been in operation since 1977 while the other stations are relatively new [8]. The monthly mean evaporation losses of about $7.5 \mathrm{~mm}$ daily amount to about $2700 \mathrm{~mm}$ per year equating to about $18 \mathrm{BCM} /$ year for a lake surface area of $6500 \mathrm{~km}^{2}$ [9].

Recent climate change is one of the major problems that faces the whole world, specially the effects of climate change on flooding and health risk [10]. With its limited water resources, Egypt will be significantly affected by climate change in the Nile basin [11,12]. In view of that, the Egyptian Ministry of Water Resources and Irrigation (MWRI) constructed climatic scenarios (low, medium, high) based on the results from 11 Global Circulation Models (GCM) for the SRES B2 emission scenario [13]. Within these models, climate change effects on air temperature and evaporation losses were studied. The results of the Climate Model ECHAM5, developed by the Max Planck Institute for Meteorology in Hamburg, predict increases of mean annual evaporation losses of about 0.47 BCM, 0.88 BCM, and 1.66 BCM for the years 2030, 2050, and 2100, respectively. Moreover, the Climate Models HadCM3, developed by the UK Hadley Centre for Climate Prediction and Research, estimated yearly evaporation losses to increase by about $0.52 \mathrm{BCM}$, $0.8 \mathrm{BCM}$, and $1.46 \mathrm{BCM}$ for the same years for the lake's surface area of $6500 \mathrm{~km}^{2}$. This means that evaporation losses will be about $3 \%$ to $10 \%$ higher by the year 2100 compared to the mean annual evaporation rates for the last 30 years [14].

Therefore, measurements must be taken to decrease these losses. The lake surface area is the main physical factor controlling the evaporation losses; consequently, solutions to reduce the surface area of the lake must be developed. Many previous studies investigated the possi- bility of minimizing the surface area through eliminating parts of open water areas, or through covering them, and even using chemical materials $[15,16]$. Worldwide, many systems are used to cover water surface areas. The major practical method is the physical covering. Continuously floating plastic covers operate as an impervious barrier that floats on the water surface and can reduce over $96 \%$ of evaporation losses from a lake. These coverings can be floating or suspended, permeable or impermeable. The life span of these covering sheets can reach up to 20 years. Each type has its own effectiveness in reducing the evaporation, its lifetime and costs $[17,18]$.

The lake area can be reduced through eliminating parts of the coastal ridges from a lake. These coastal ridges are usually shallow lagoons, locally known as khors. HADR khors have shallow water depth and low water quality. Previous studies on HADR considered eliminating some khors [19]. However, they did not take into account how closing these khors would affect the lake hydrological characteristics. They studied only the lake's surface areas due to the lack of a digital elevation model (DEM) for the lake. Also, they accounted only for the current climate conditions without considering the effect of subsequent climate changes. This study aims to model HADR hydrological features through creating an up-to-date high resolution DEM for the lake, which simulates the lakebed after erosion and sedimentation events of the years following the construction of the HAD. In addition, the lake meteorological characteristics are also modeled. This study considers the effect of the elimination process on the lake hydrological characteristics and the consequence of climate changes on the evaporation losses via four case studies. Each case discusses individually the elimination of four khors: Kalabsha; El-Alaky; Sara; Korosko. The evaporation losses for each khor are estimated according to data available from the nearest meteorological station.

According to decree 203/2002, the study takes into account leaving two $\mathrm{km}$ around the lake as a buffer zone, to protect the water quality of Lake Nasser. The decree states that it is forbidden to undertake actions or activities or procedures which would lead to the destruction, damage, or degradation of the natural environment within the buffer zone of two kilometers around HADR [20].

\section{Material and Methods}

In order to investigate the khors that could be eliminated, HADR was modeled using hydrological and meteorological databases as shown in Figure 2. Meteorological and hydrological data for the lake were collected for the years since the HAD's construction and were used in creating these databases. To study the lake's morphological features, satellite images and lake survey were also used. 


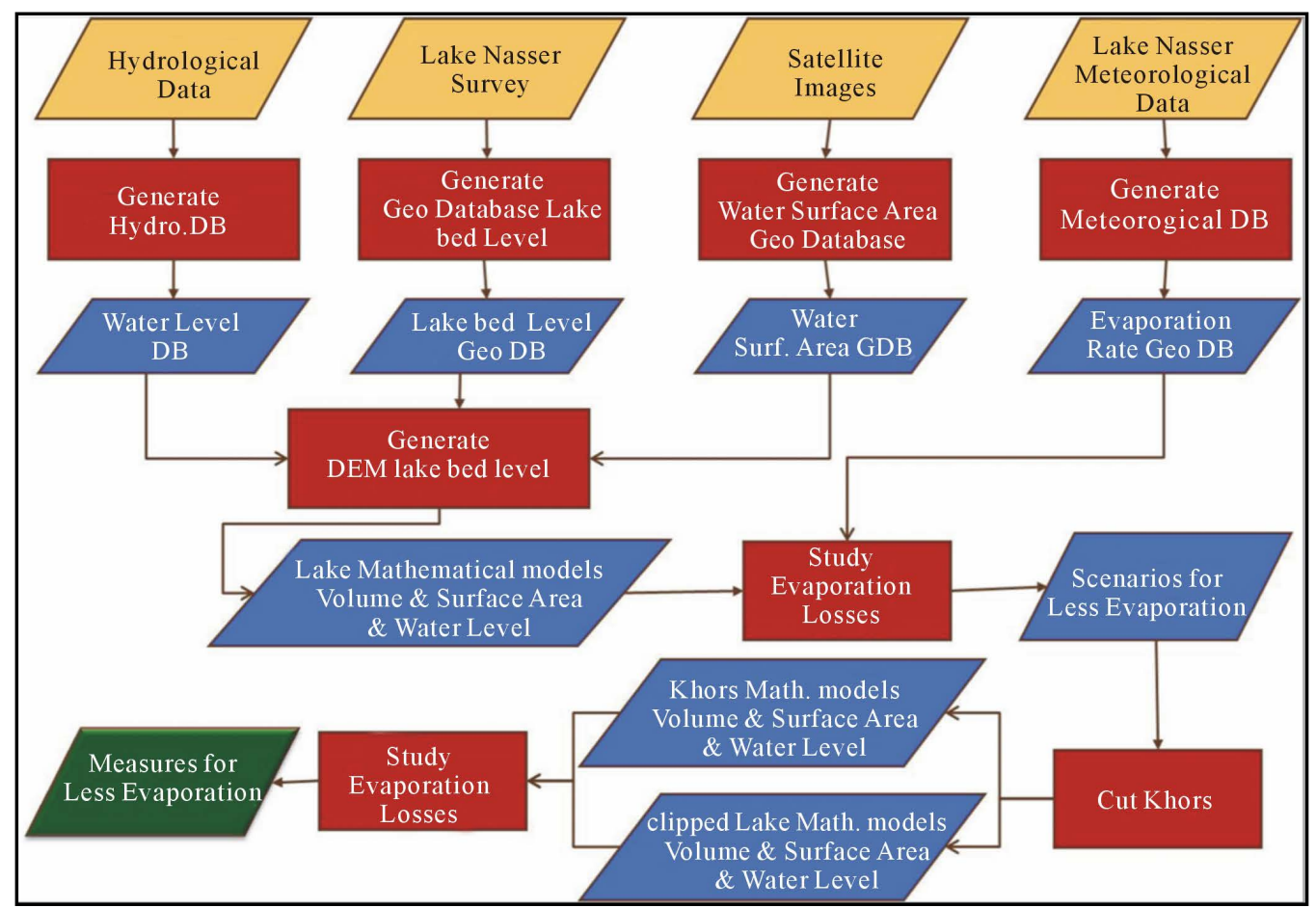

Figure 2. Methodology for reducing the evaporation losses of the HADR.

\subsection{Study Area}

The largest khor in HADR is Khor Toshka. This khor cannot be eliminated due to its function as a spillway for the HAD. Furthermore, the intake of the Shiekh Zayed canal is located on this khor. This canal will irrigate the new reclamation lands in the South of Egypt [21]. Therefore, Khor Kalabsha and Khor El-Alaky were selected as large khors to be studied. In addition, Khor Sara and Khor Korosko with their small surface areas were selected due to their high evaporation rates. Lake maximum level was $181.6 \mathrm{~m}$ AMSL Thus, the khors' surface areas were measured with respect to it. The evaporation loss rates for each khor was estimated using the annual distribution of the evaporation losses over the lake presented in Figure 3.

Khor Kalabsha is the second largest khor in the lake. It is about $30 \mathrm{~km}$ upstream of the HAD, in the Western Desert. It has a surface area of $600 \mathrm{Km}^{2}$, about $10 \%$ of the lake's entire area. It loses about $2700 \mathrm{~mm}$ of water annually, due to evaporation. Thus, it is expected that eliminating it will lead to a substantial reduction in evaporation losses. Khor El-Alaky is about $100 \mathrm{~km}$ upstream of the HAD and extends into the Eastern Desert. It has a large surface area of $500 \mathrm{~km}^{2}$ and experiences $2500 \mathrm{~mm}$ evaporation losses annually. Thus, it is expected that eliminating this khor will help also in substantially decreasing evaporation losses. The other two khors investigated in this study, Koroso and Sara, are not as large as khors El-Alaky or Kalabasha; however, both experience high evaporation rates. Khor Korosko is found in the Eastern Desert at about $180 \mathrm{~km}$ upstream of the HAD and covers about $103 \mathrm{~km}^{2}$ at water level $182 \mathrm{~m}$. It is steep sided and relatively narrow with a rocky bottom. It loses about $3000 \mathrm{~mm}$ annually through evaporation. Khor Sara is located about $325 \mathrm{~km}$ upstream of the HAD reaching into the Western Desert. It is one of the miniature khors in HADR and has a surface area of only 50 $\mathrm{km}^{2}$. It suffers from high evaporation losses of about $3100 \mathrm{~mm}$ per year.

\subsection{HADR Meteorological Database (HADRMTDB)}

The lake is meteorologically monitored to estimate the daily evaporation losses by six meteorological stations covering the entire lake. Data on daily evaporation losses at each station since its operation until 2010 were stored and assembled in a new meteorological database for HADR (HADRMTDB). Thus the daily, monthly and annually averages have been estimated. The mean daily evaporation losses per month for the entire lake, and the mean annual evaporation losses per station are presented in Figure 3. The annual evaporation losses estimated from these stations were converted into a GIS layer, and interpolated to produce the distribution of mean annual evaporation losses along the lake for remote areas as shown in Figure 3. Using the HADRMTDB, the mean evaporation losses are estimated to be $7.4 \mathrm{~mm} /$ day, equal to $2700 \mathrm{~mm} /$ year. 


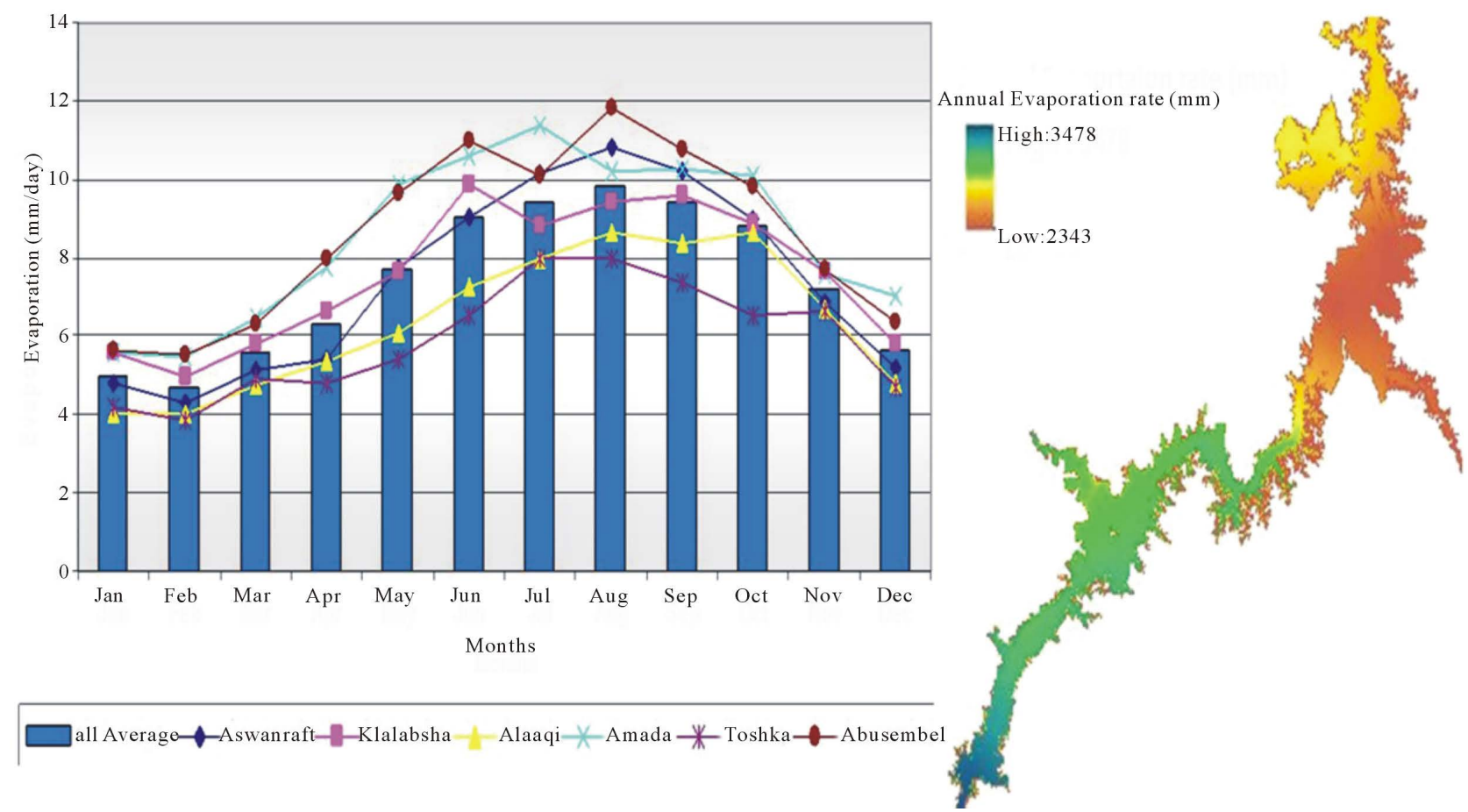

Figure 3. Chart for the mean monthly evaporation rate reflected by the meteorological stations situated along the lake in $\mathrm{mm} / \mathrm{day}$, and the distribution of the annual evaporation losses along the HADR in $\mathbf{m m}$.

\subsection{HADR Hydrological Database (HADRHYDB)}

The lake surface water level and the lake flow measured daily at Aswan station since 1964 were stored and assembled in a new hydrological database (HADRHYDB). There are more than 16000 water level records covering the period from 1964 to July 2010 as shown in Figure 4. The lowest water level of $150.62 \mathrm{~m}$ AMSL was recorded on $21^{\text {st }}$ July 1988. The highest level of $181.6 \mathrm{~m}$ AMSL was measured during the period from 10th to14th November 1999. According to the HADRHYDB, the mean water level is about $178 \mathrm{~m}$ AMSL.

\subsection{Landsat Imagery}

Lake Nasser covers large inaccessible areas, thus satellite imagery was used to define the lake actual morphology. New imagery was needed due to the lack of new up-todate topographic maps and the fact that the lake edges at different elevations have changed due to erosion events since HAD construction. Landsat ETM7 and Landsat TM5 were utilized in constructing new contour lines for HADR at different elevations. The lake is generally captured by a set of four images. Thus, over 300 images were downloaded to select the appropriate sets for each water level. The surface water level for every set was identified by using the developed HADRHYDB database. Hence, proper sets with similar water levels were selected and used in identifying the surface water area as listed in Table 1. The lake sides have a smooth incline, thus a step of $1.5 \mathrm{~m}$ is adequate to embrace various surface areas. Twenty imagery sets were used, consisting of 80 Landsat images for the years 1984 to 2005 . The least surface area was obtained from the imagery set of August 1987 at water level of a about $154.5 \mathrm{~m}$ AMSL, while the largest area was attained from the imagery set of November 1999 when the lake reached its peak water level of $181.6 \mathrm{~m}$ AMSL.

All the images were transformed together. Each set of four images was mosaiced into one imagery using ERDAS IMAGINE. Band 4 is the near infrared band with wave length ranging between 0.77 and 0.90 . Consequently, it emphasizes biomass content and shorelines as stated on USGS website

http://landsat.usgs.gov/best_spectral_bands_to_use.php.

Thus the mosaiced imagery sets were imported into ENVI EX to delineate lake shorelines using band 4. The outputs of lake delineation were exported to ERADS IMAGINE to manually edit the edges to correct the classification errors occurring around the lake shore lines. The adjusted water layers were transformed then to shape files. These shape files were subsequently edited to eradicate all small polygons. Hence, the main polygon for each altitude was converted to a polyline representing contour lines of individual water levels. These polylines were attached to a new shape file layer for the contour lines at $154.5 \mathrm{~m}$ to $181.6 \mathrm{~m}$ AMSL as shown in Figure 5. The interpolation of these individual contour lines was 


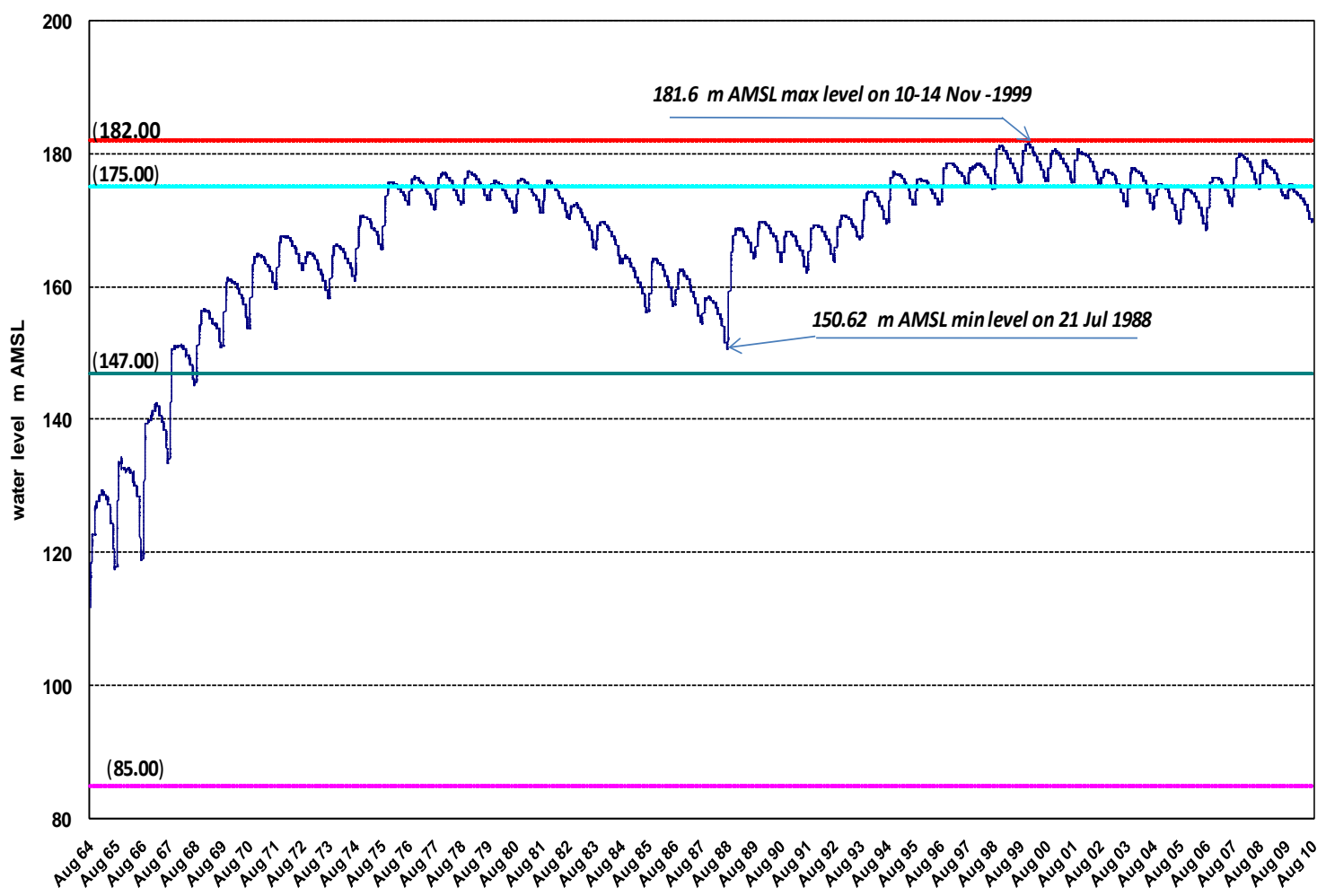

Figure 4. Water level measured at Aswan station from 1964 till 2010.

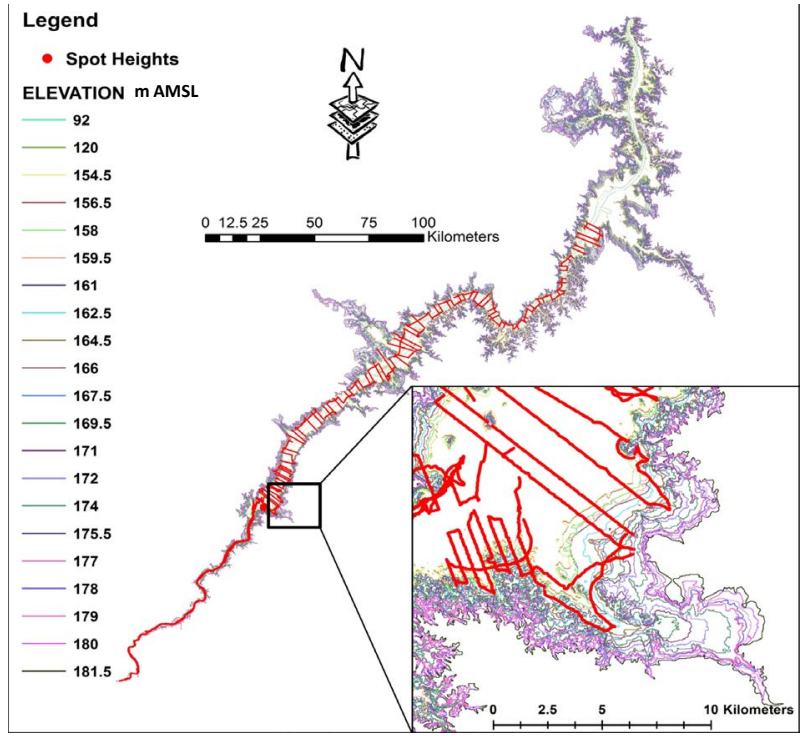

Figure 5. Contour lines extracted from satellite images, and spot heights computed from the HADR survey in 2007.

needed for water levels over $154 \mathrm{~m}$ and below $182 \mathrm{~m}$ AMSL. Using old aerial photo acquired in the 1960s which has the original Nile morphology before HAD construction, the contour line of $92 \mathrm{~m}$ was extracted.

\subsection{Lake Survey}

Each year, the MWRI conducts a bathymetric survey for
Lake Nasser, to identify the lakebed along many sections as shown in Figure 5. For altitudes below $154 \mathrm{~m}$, the lakebed elevations computed using the bathymetric survey, were used as spot heights. Moreover, the MWRI monitors lake water quality and performs a geological survey along the lake shores. Past surveys showed that the sedimentation rate is particularly high in Lake Nubia which required surveying as presented in Figure 5. Elba visited HADR in January 2007, spending 30 days on the survey ship collecting the required data. Figure 5 shows 200,000 points along the lake where water depths were measured in 2007. The depths are subtracted from the lake surface water level measured during this phase to detect the lake bed altitudes above mean sea level. These levels are generated as point shape file. The generated layer was utilized as spot heights for the lake levels below $154 \mathrm{~m}$ within the lake Egyptian division, and below $160 \mathrm{~m}$ within the Sudan division due to the high sedimentation rates there [9].

\subsection{Topographic Maps}

Since the area around HADR was not subject to any erosion or sedimentation events, old topographic maps of scale 1:100,000 produced in the 1960s before HAD construction was used to delineate the contour lines for the region outside the lake margin at its maximum water level of $181.6 \mathrm{~m}$ AMSL The contour lines within the lake 
margin were erased using ARCGIS because they had changed.

\section{Results and Discussion}

\subsection{HADR Digital Elevation Model (HADRDEM)}

The DEM was created using the contour lines extracted from the satellite images, the spot heights measured from the bathymetric survey of 2007, and the old topographic maps. It was generated using the Topo to raster interpolation method in ARCGIS with $25 \mathrm{~m}$ spatial resolution for the area extending between $21^{\circ} \mathrm{N}$ and $24^{\circ} \mathrm{N}$ and $31^{\circ} 30^{\prime} \mathrm{E}$ and $33^{\circ} 30^{\prime} \mathrm{E}$. To study the lake hydrological features, HADR DEM (HADRDEM) was isolated using the lake boundary at $182 \mathrm{~m}$ as demonstrated in Figure 6.

\subsection{HADR Mathematical Models}

HADRDEM was used initially to build mathematical models for HADR hydrological characteristics. Three mathematical models were built to indicate the relationship between the different hydrological characteristics: water level versus surface area; water level versus lake

Table 1. List of utilized imagery with acquisition dates and their water level of Lake Nasser in meters AMSL.

\begin{tabular}{cccccc}
\hline No. & $\begin{array}{c}\text { Acquisition } \\
\text { Dates }\end{array}$ & $\begin{array}{c}\text { Water } \\
\text { Level }\end{array}$ & No. & $\begin{array}{c}\text { Acquisition } \\
\text { Dates }\end{array}$ & Water Level \\
\hline 1 & Aug-87 & 154.50 & 10 & Jan-98 & 169.50 \\
2 & Mar-88 & 156.50 & 11 & Jul-05 & 171.00 \\
3 & Jan-88 & 158.00 & 12 & Jul-03 & 172.00 \\
4 & Mar-95 & 159.50 & 13 & Aug-03 & 174.00 \\
5 & May-85 & 161.00 & 14 & Jul-98 & 175.50 \\
6 & Dec-86 & 162.50 & 15 & Jun-02 & 177.00 \\
7 & Sep-84 & 164.50 & 16 & Mar-99 & 179.00 \\
8 & Jun-84 & 166.00 & 17 & Jan-99 & 180.00 \\
9 & Apr-90 & 167.50 & 18 & Nov-99 & 181.60 \\
\hline
\end{tabular}

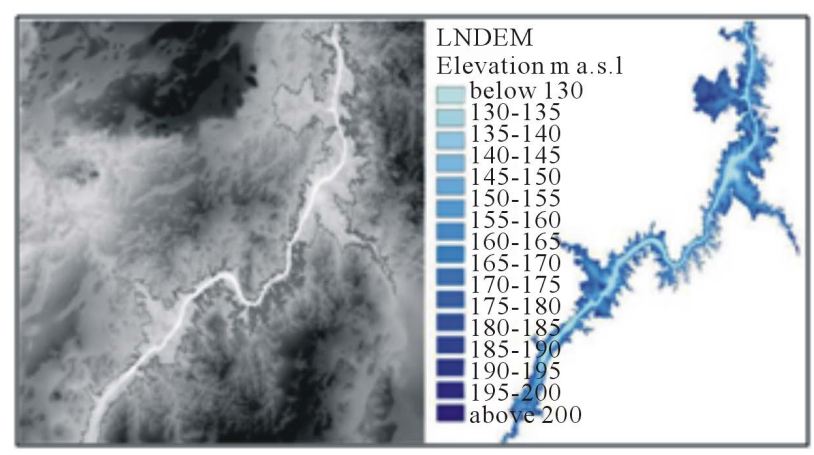

Figure 6. DEM for HADR and the surrounding area and the isolated HADRDEM. volume; and surface area versus lake volume. The number of pixels at each elevation were imported from HADRDEM to excel files, to estimate the lake surface area and water volume per meter of lake altitude. Elevation, calculated area and volume were analyzed to estimate the proper curve using regression functions in SPSS, and develop the proper type for each equation. It was found that power equations fits the obtained mathematical models as illustrated in Equations (1)-(3).

$$
\begin{gathered}
\mathrm{WL}=37.724 \mathrm{~A}^{0.184} \\
\mathrm{WL}=96.332 \mathrm{~V}^{0.126} \\
\mathrm{~A}=74.833 \mathrm{~V}^{0.894}
\end{gathered}
$$

where WL = Water Level in m AMSL, A = Surface Area in $\left(\mathrm{km}^{2}\right)$, and $\mathrm{V}=$ Water Volume in (BCM). Using equation 2, the lake volume was estimated to be 150 BCM at the water level of $181 \mathrm{~m}$ AMSL. This implies that the lake water capacity is decreased by about 6 BCM. This reduction is due to the $5 \mathrm{BCM}$ sediment deposits in the Sudan portion and $1 \mathrm{BCM}$ sediment deposits within the Egyptian part. Equation (1) was used to estimate the current evaporation losses, with respect to each water level, using the rates stored in the HADRMTDB.

\subsection{HADRDEM and Mathematical Model Verification}

The HADRDEM was evaluated to investigate its quality and significance in estimating the surface area and the water volume of the HADR. Figure 7 shows a scatter diagram of the surface area estimated by the HADRDEM and the NWS. The points are highly correlated and the relationship between them can be presented with a linear equation. The differences between both areas are \pm 100 $\mathrm{km}^{2}$ at maximum due to the morphological changes of the HADR for the last four decades. Figure 8 shows the HADR's altitudes and the corresponding water volume estimated by the HADRDEM and the NWS. Both lines are parallel and have a difference of about 7 BCM between both volumes due to the sediment events over the last five decades.

The developed mathematical models were also evaluated to investigate their significance in estimating the surface area and the water volume of the HADR with respect to the water levels. Figure 9 shows a scatter diagram depicting the surface area estimated by the HADRDEM and from the developed mathematical model. The points are highly correlated and the relationship between them can be presented as a linear equation with a slope of one. Figure 10 shows a scatter diagram between the water volume estimated by the HADRDEM and the developed mathematical model. The points are highly correlated and the relationship between them can be presented as a linear equation with a slope of one. 


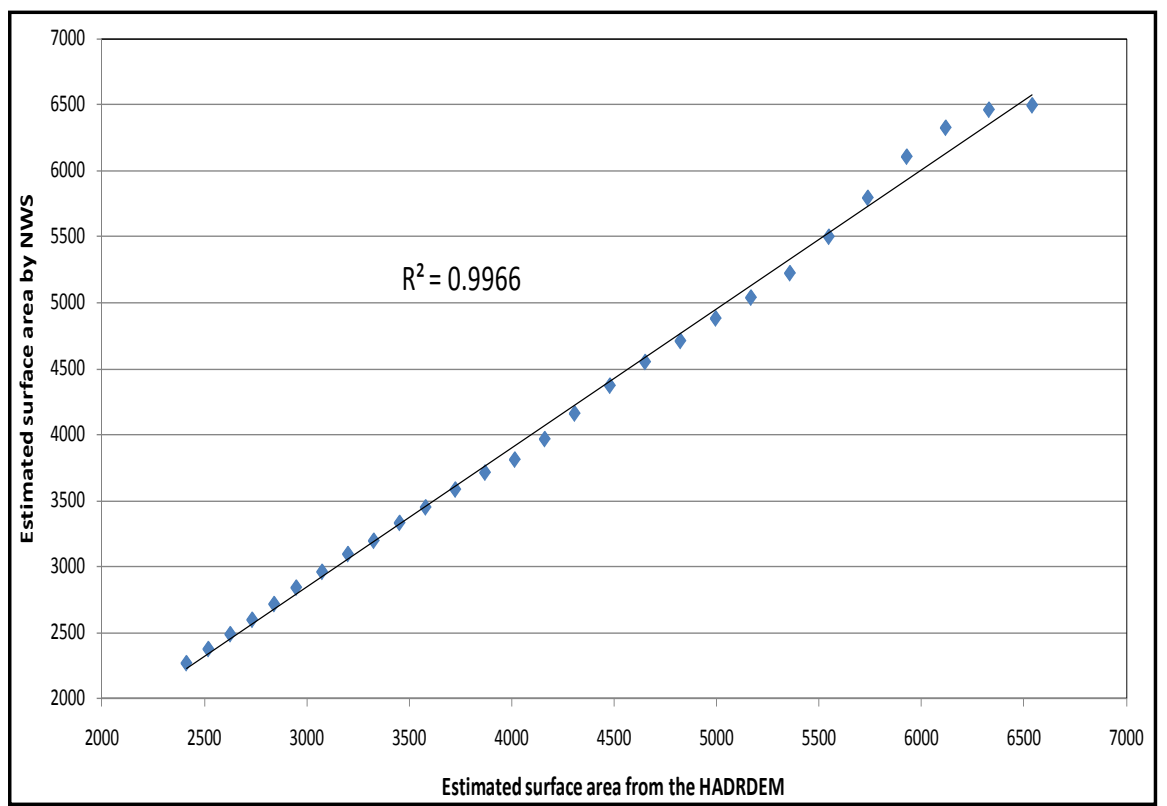

Figure 7. Scatter diagram for the surface area estimated by the HADRDEM and by the NWS.

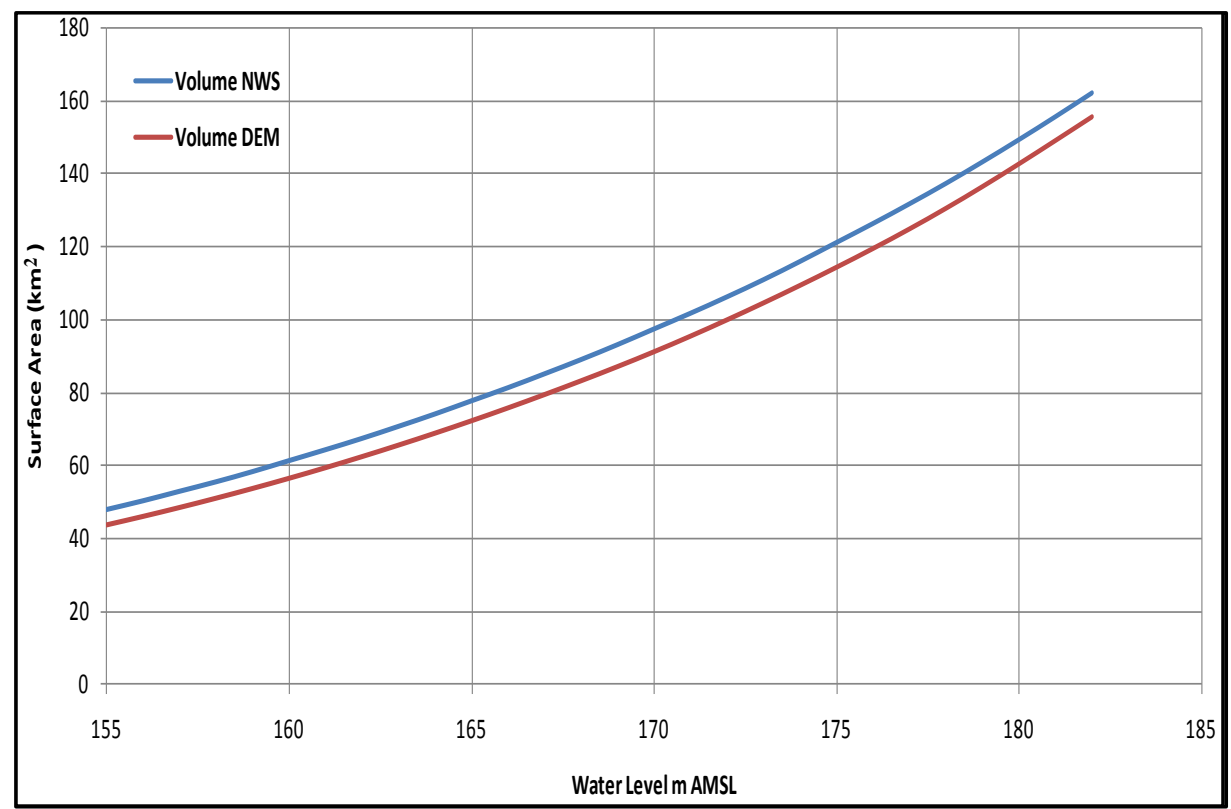

Figure 8. The HADR's altitudes and the correspondence water volume estimated by the HADRDEM and by the NWS.

\subsection{Case Study}

To study the effect of eliminating the chosen khors, the four khors were isolated from the HADRDEM, for analysis of their hydrological characteristics individually. Using the isolated DEMs, average depth, surface area, and water volume were computed for each khor. Some alternatives were suggested to select the best location for eliminating each khor. The alternatives were analyzed and evaluated according to the cross section of the dam; the length of the dam; the saved surface area downstream the dam; and the water volume downstream of the dam.
According to these criteria, the most cost-effective and practical solution for each khor was selected. Each khor was removed from HADRDEM at the selected sections in order to study the impact of eliminating them on hydrological features of HADR individually. The new DEMs were again investigated to determine the new surface area and the new lake water volume for each elevation, and to build new mathematical models between them.

For the four case studies, the newly constructed mathematical models were used to estimate the saved eva- 


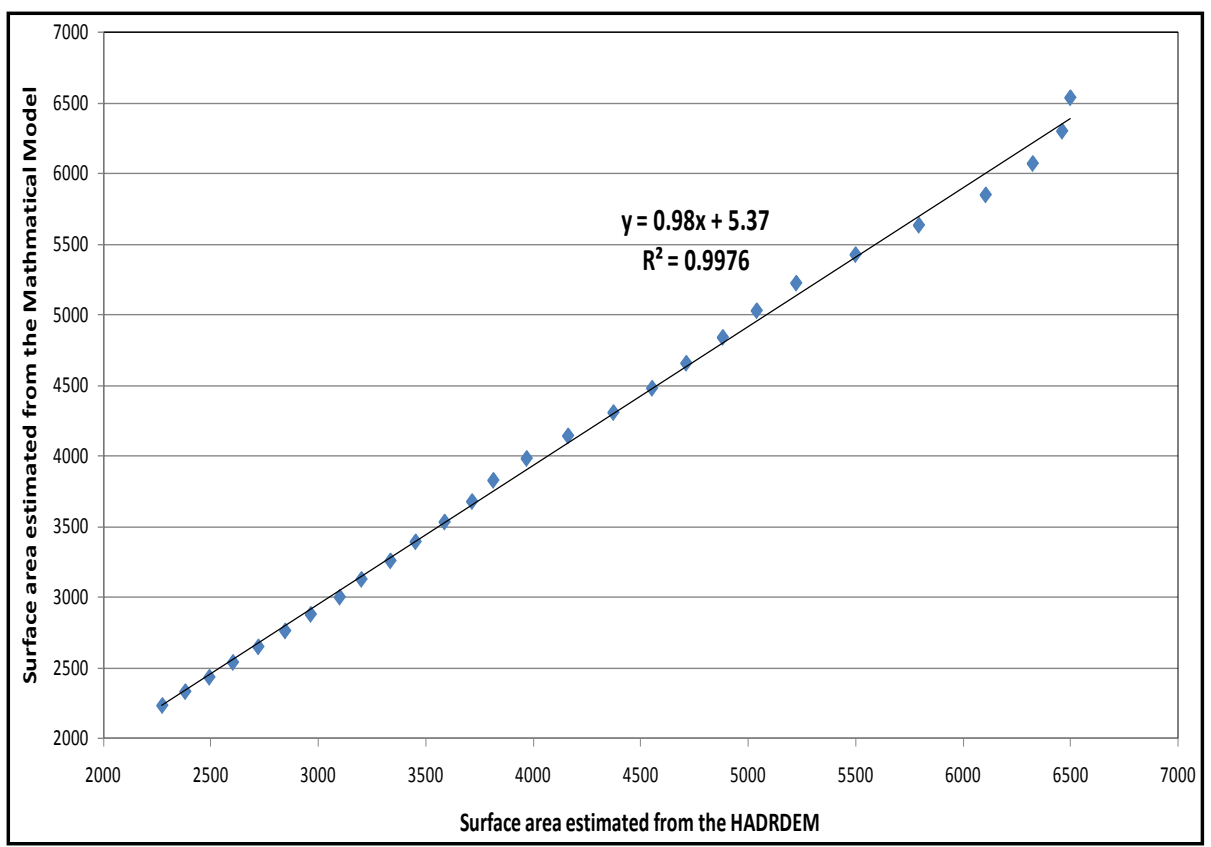

Figure 9. Scatter diagram of the HADR's surface area estimated by the HADRDEM and the developed mathematical model.

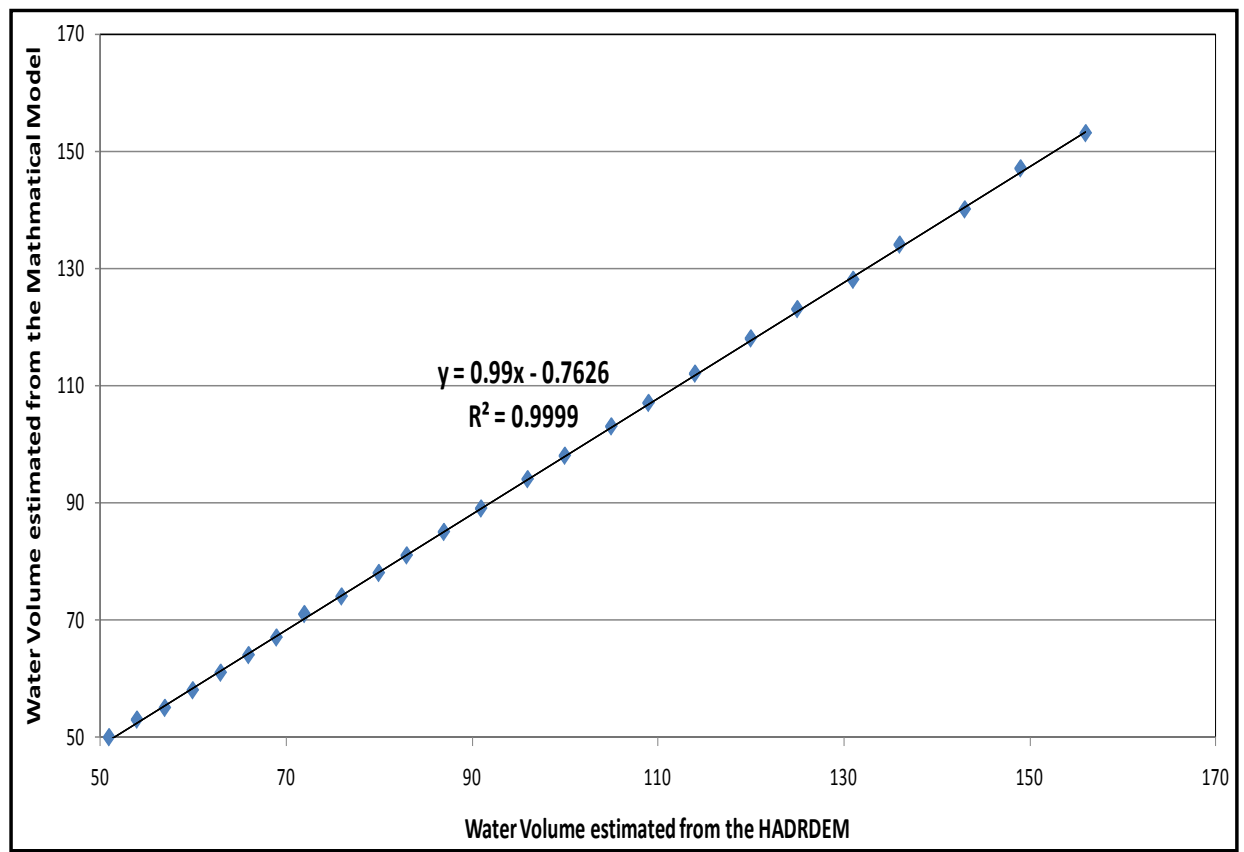

Figure 10. Scatter diagram of the HADR water volume estimated by the HADRDEM and the developed mathematical model.

poration losses at each water level under current climatic conditions. According to the MWRI prepared climatic scenarios, the ECHAM5 model predicts that due to climate change impact evaporation losses will increase by about $2.7 \%$ in $2030,5 \%$ in 2050 , and $10 \%$ in 2100 , while HadCM3 expects higher evaporation by about $3 \%$ in $2030,4.5 \%$ in 2050 , and $8.5 \%$ in 2100 [14]. These rates are used in forecasting the expected reduced evaporation losses after eliminating each khor at each water level.

\subsubsection{Khor Kalabsha}

By isolating Khor Kalabsha DEM, it is found that the khor mean depth is $10 \mathrm{~m}$ at $182 \mathrm{~m}$ level, and can reach up to $32 \mathrm{~m}$. Many alternatives were analyzed to select the prime alternative for eliminating this khor as shown in Figure 11. It is obvious that section 4 has the least cross section area and can save almost the same area and volume as the other sections. Hence alternative 4 is the best location for eradicating Khor Kalabsha. Numerous pro- 

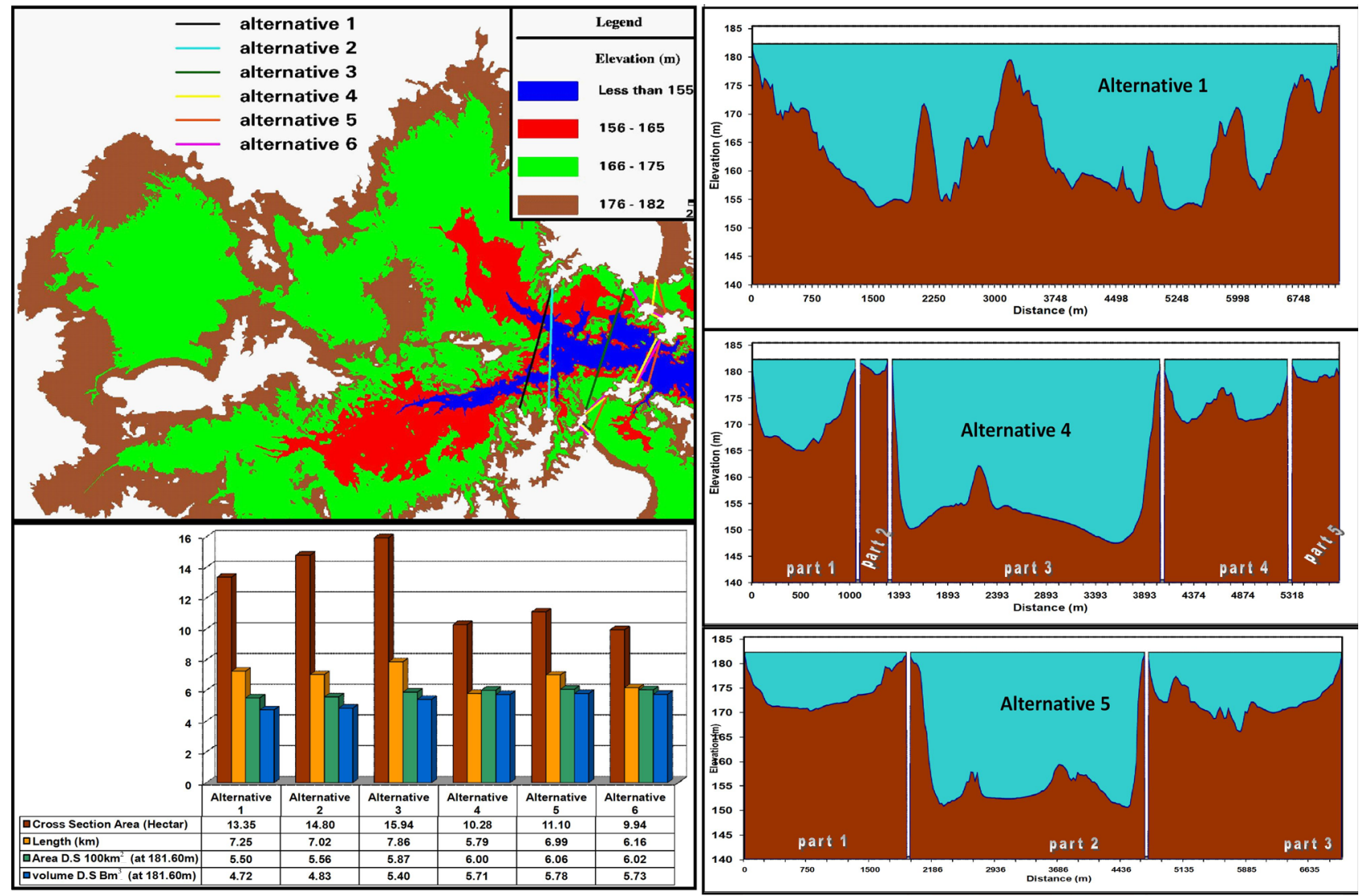

Figure 11. Assessment of the alternatives for removing Khor Kalabsha.

cedures are available to eliminate this khor such as building dams, filling the khor area with sediment or covering the water with plastic sheets used for reducing the evaporation losses over open lakes.

The results of the elimination process at section 4 are presented in Figure 12. The lake water levels at same water volumes will rise by at most $90 \mathrm{~cm}$ after eliminating Khor Kalabsha. This is due to adding over 5 BCM of water volume located previously in Khor Kalabsha at $181 \mathrm{~m}$ AMSL. The remaining lake area will be about $6000 \mathrm{~km}^{2}$ at water level $181 \mathrm{~m}$ a.s.l reducing the evaporation area by about $600 \mathrm{~km}^{2}$ at most. The mean annual evaporation rate over Khor Kalabsha is about $2700 \mathrm{~mm}$. Thus, the saved evaporation loss is estimated to be 1.7 BCM under current climatic conditions. The effects of climate changes are listed in Table 2. The saved evaporation losses can reach up to about two BCM by year 2100. Moreover, the khor area could be used as agricultural land to add more than $500 \mathrm{~km}^{2}$ to the reclamation land in Egypt.

\subsubsection{Khor El-Alaky}

By separating Khor El-Alaky DEM, it is found that the bed elevations of the khor vary from $150 \mathrm{~m}$ to $182 \mathrm{~m}$. The different alternatives to close the khor are shown in
Figure 13. As alternatives 7 and 8 have a huge cross section area, they should be abandoned for economic reasons. Alternatives 1, 2, 5, 6 will save only around 100 $\mathrm{km}^{2}$. This area is quite small to perform any measures there. Hence, alternatives 3 and 4 with larger than 160 $\mathrm{km}^{2}$ area should be considered. Section 3 has a less cross section area than section 4 and reduces about the same surface area. Therefore, it is recommended that a dam be constructed at section 3 and this will eliminate about 167 $\mathrm{km}^{2}$.

The results of eliminating the khor at section 3 are presented in Figure 14. Comparing the lake water level before and after eliminating Khor El-Alaky at same water volumes, the lake water level will rise by at most 30 $\mathrm{cm}$ after eliminating the khor. This is due to adding over 1.9 BCM of water volume located previously in Khor ElAlaky at an elevation of $181 \mathrm{~m}$. The clipped lake area will be about $6340 \mathrm{~km}^{2}$ at water level $181 \mathrm{~m}$ a.s.l reducing the evaporation area of about $160 \mathrm{~km}^{2}$ at most. For a mean annual evaporation rate of $2500 \mathrm{~mm}$ over Khor Elalaky, the saved evaporation losses from the lake surface are estimated to be about 0.4 BCM under the present climate. The effects of climate change are listed in Table 3. It is found that the reduced evaporation losses can reach up to about $0.45 \mathrm{BCM}$ by the end of the $21^{\text {st }}$ century. 


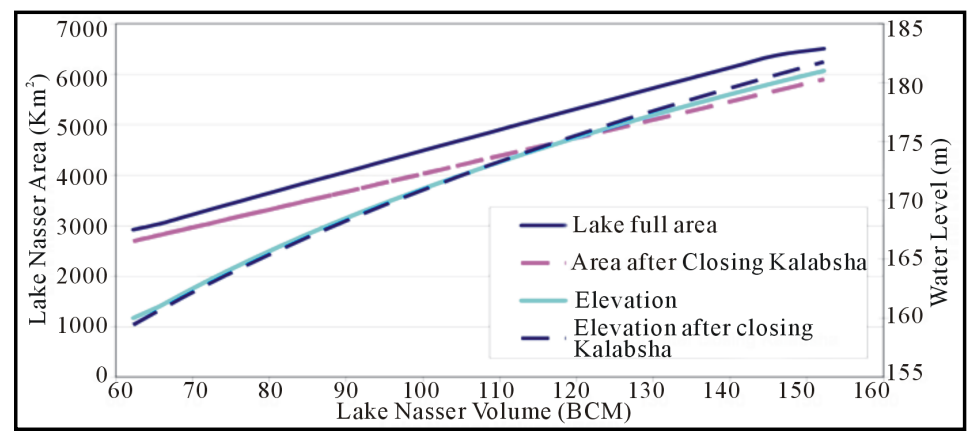

Figure 12. The effect of removing Khor Kalabsha on HADR hydrological characteristics.

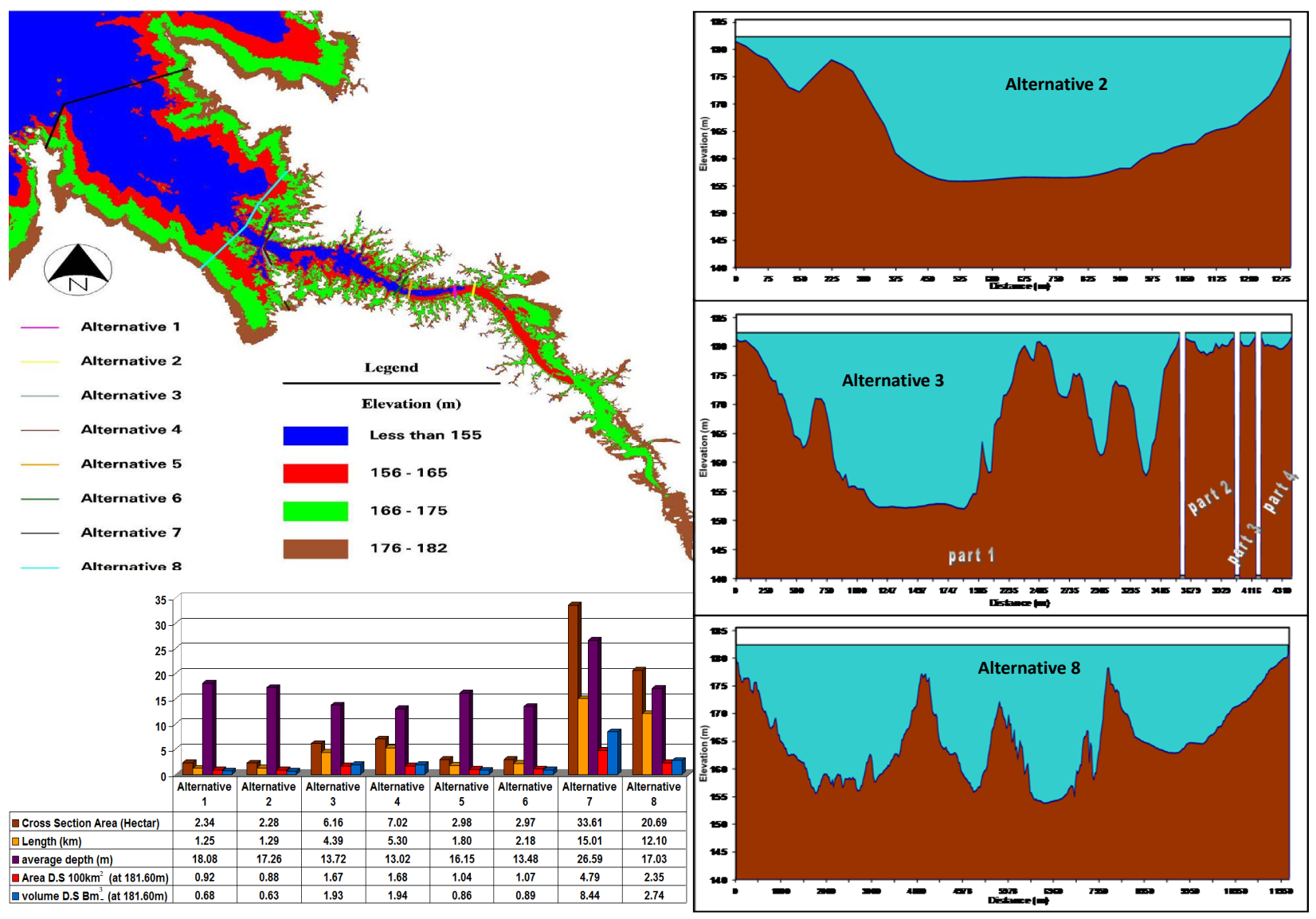

Figure 13. Assessment of the alternatives for removing Khor El-Alaky.

Table 2. Expected saved evaporation losses from Lake Nasser due to eliminating Khor Kalabsha under the current climate conditions and according to the ECHAM5 and HadCM3 climate models.

\begin{tabular}{ccccccccc}
\hline \multirow{2}{*}{ Elevation } & \multirow{2}{*}{ Current climate conditions } & \multicolumn{3}{c}{ ECHAM5 } & \multicolumn{3}{c}{ HadCM3 } \\
\cline { 3 - 8 } & & 2030 & 2050 & 2100 & 2030 & 2050 & 2100 \\
\hline 160 & 0.149 & 0.153 & 0.156 & 0.163 & 0.153 & 0.156 & 0.161 \\
165 & 0.290 & 0.297 & 0.304 & 0.317 & 0.298 & 0.303 & 0.314 \\
170 & 0.567 & 0.583 & 0.596 & 0.621 & 0.584 & 0.593 & 0.615 \\
175 & 1.006 & 1.033 & 1.057 & 1.101 & 1.036 & 1.052 & 1.090 \\
180 & 1.572 & 1.614 & 1.651 & 1.721 & 1.619 & 1.644 & 1.703 \\
182 & 1.626 & 1.670 & 1.708 & 1.780 & 1.674 & 1.700 & 1.761 \\
\hline
\end{tabular}


Table 3. Expected saved evaporation losses from Lake Nasser due to eliminating Khor El-Alaky under the current climate conditions and according to the ECHAM5 and HadCM3 climate models.

\begin{tabular}{|c|c|c|c|c|c|c|c|}
\hline \multirow{2}{*}{ Elevation } & \multirow{2}{*}{ Current climate conditions } & \multicolumn{3}{|c|}{ ECHAM5 } & \multicolumn{3}{|c|}{ HadCM3 } \\
\hline & & 2030 & 2050 & 2100 & 2030 & 2050 & 2100 \\
\hline 160 & 0.081 & 0.084 & 0.086 & 0.089 & 0.084 & 0.085 & 0.088 \\
\hline 165 & 0.118 & 0.122 & 0.124 & 0.130 & 0.122 & 0.124 & 0.128 \\
\hline 170 & 0.172 & 0.176 & 0.180 & 0.188 & 0.177 & 0.180 & 0.186 \\
\hline 175 & 0.251 & 0.258 & 0.264 & 0.275 & 0.259 & 0.263 & 0.272 \\
\hline 180 & 0.392 & 0.402 & 0.412 & 0.429 & 0.404 & 0.410 & 0.425 \\
\hline 182 & 0.416 & 0.427 & 0.437 & 0.456 & 0.429 & 0.435 & 0.451 \\
\hline
\end{tabular}

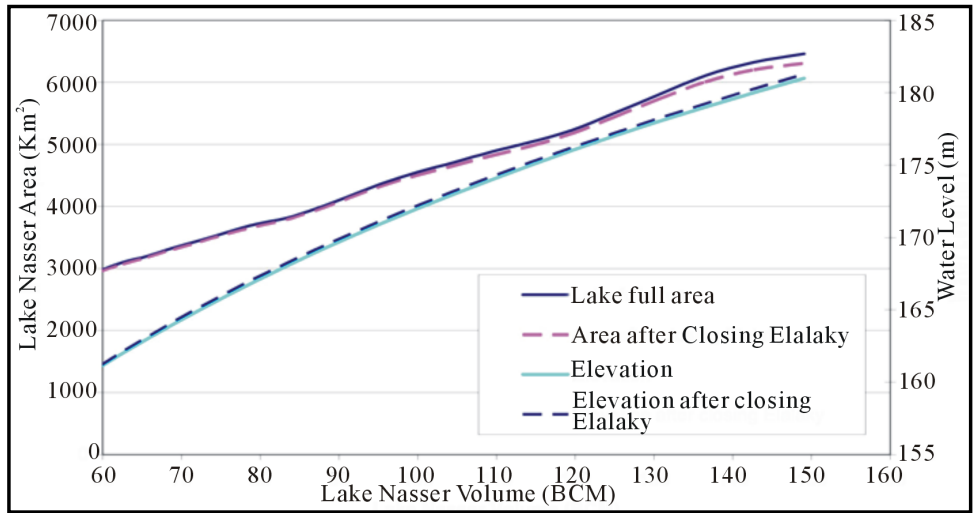

Figure 14. The effect of removing Khor El-Alaky on HADR hydrological characteristics.

\subsubsection{Khor Korosko}

By isolating Khor Korosko DEM, the khor mean depth is estimated to be $27 \mathrm{~m}$. Two alternatives to close the khor were analyzed as shown in Figure 15. A dam is suggested to close this Khor at section 1 since it has less cross section area. The results of the elimination process are presented in Figure 16. For a mean annual evaporation rate of $3000 \mathrm{~mm}$ over Khor Korosko, the saved evaporation losses from the lake surface are expected to be about 0.3 BCM under the existing climatic conditions. The effects of climate change are given in Table 4 . The saved evaporation losses can reach about 0.34 BCM maximum by year 2100. This Khor has many fingers with tiny width averaging $500 \mathrm{~m}$. Thus, a covering system can be used to decrease the lake surface area. The lake hydrology will not be affected due to reducing the lake surface area without affecting its volume.

\subsubsection{Khor Sara}

By separating Khor Sara DEM, it is found that the khor depths reach up to $32 \mathrm{~m}$. Four alternatives were analyzed as shown in Figure 17. The results indicate that the reduced areas are quite small and required dams would be long with huge cross sections. On the other hand this area is experiences a high annual evaporation rate of 3100 $\mathrm{mm}$. Therefore, it is recommended that a covering procedure be applied to this khor, to decrease the lake sur- face area by about $40 \mathrm{~km}^{2}$. This measure would result in reducing the evaporation losses by about $0.12 \mathrm{BCM}$ annually. The general lake hydrology will not be affected due to only reducing the lake surface area without decreasing its volume. Due to climate change, the predicated saved evaporation losses could reach about 0.13 BCM by year 2100 as listed in Table 5 .

\section{Concluding Remarks}

This paper shows the importance of up-to-date DEM for HADR to study its hydrological features and the effect of applying measures that can reduce evaporation losses. The study verified that in the year 2100, eliminating the Khors can decrease the evaporation losses by about 2 BCM for Khor Kalabsha, over 0.45 BCM for El-Alaky, about 0.34 BCM for Korosko, and about 0.13 BCM for Khor Sara, according to the ECHAM5 climate model.

This study recommends that dams be built to close Khor Kalabsha at section 4 to eliminate $600 \mathrm{~km}^{2}$ from the lake surface area and Khor El-Alaky at section 3 to remove over $160 \mathrm{~km}^{2}$. Building both dams can save up to $2.5 \mathrm{BCM}$ by end of this century. It is recommended that suitable plastic covers overlay Khor Korosko, and Khor Sara to save an additional 0.5 BCM by year 2100. However, the choice of the most suitable coverage type is beyond the focus of this paper and will be part of a sepa- 


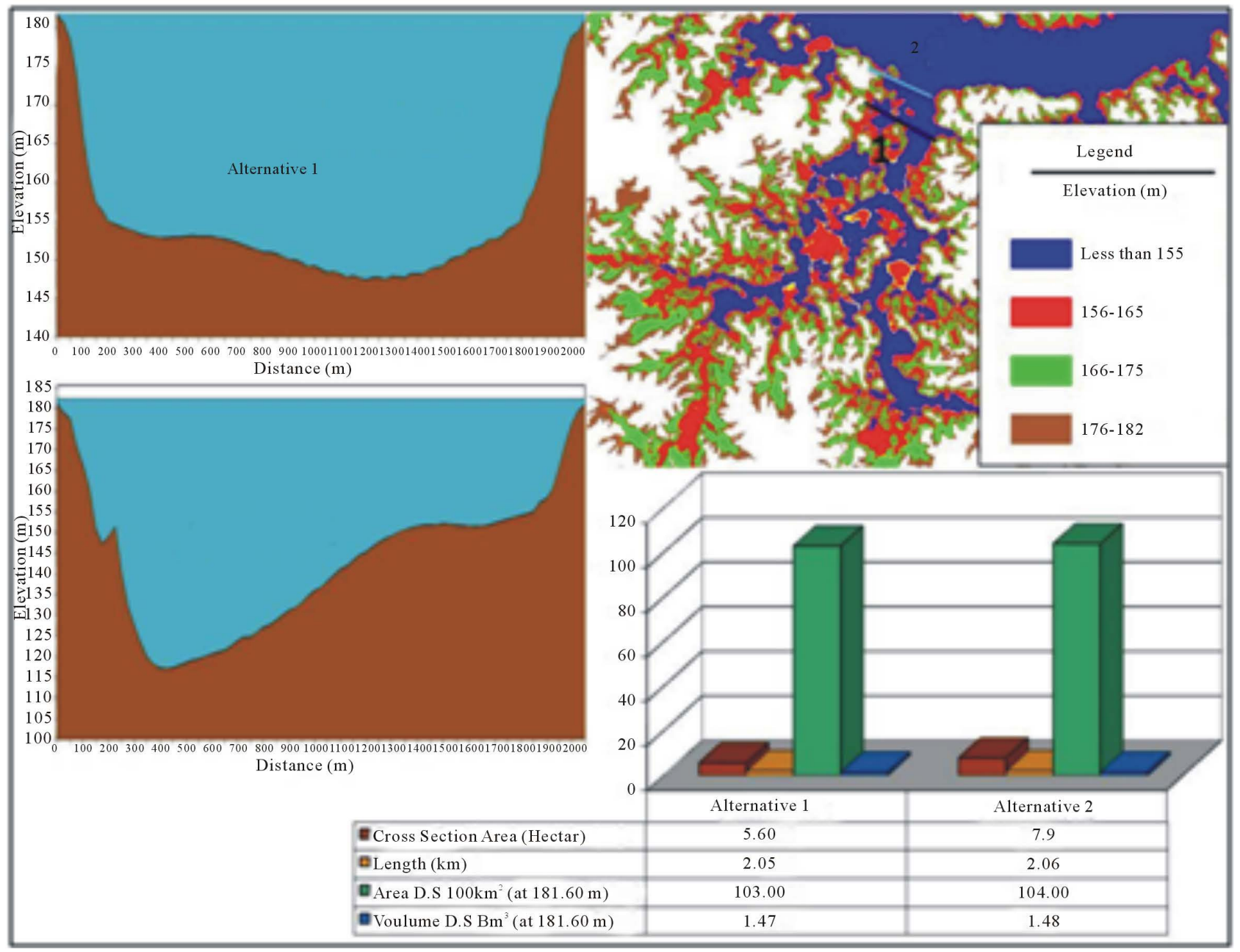

Figure 15. Assessment of the alternatives for removing Khor Korosko.

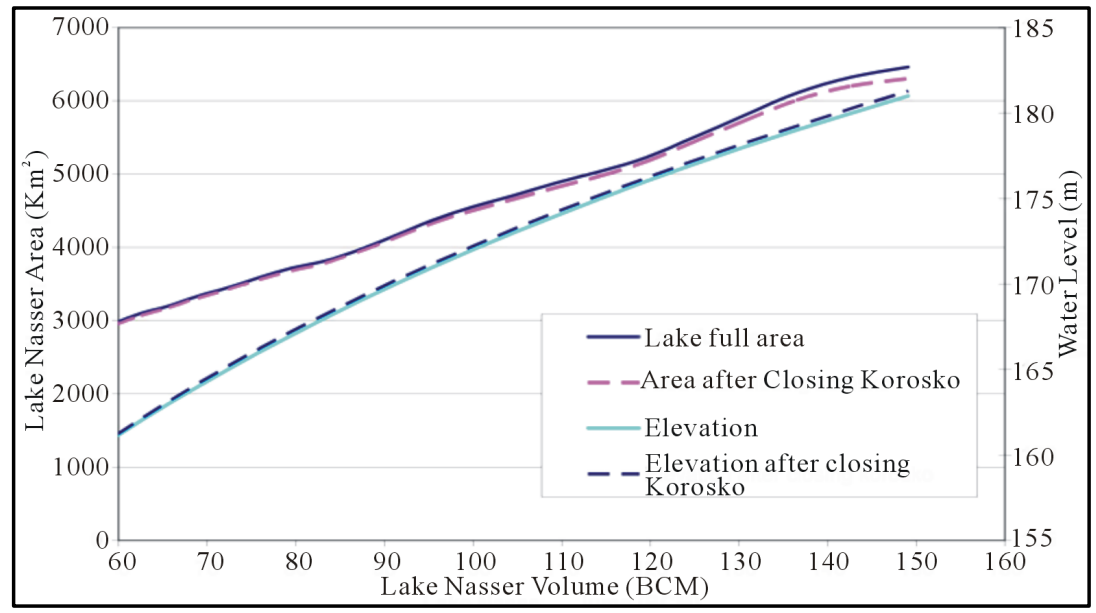

Figure 16. The effect of removing Khor Korosko on HADR hydrological features.

rate feasibility study on choosing the most effective and economic type for covering the open water areas. Overall, by the end of the $21^{\text {st }}$ century, building dams and covering surface areas at strategic locations can save up to 3
BCM, equals to $5.5 \%$ of Egypt share from HADR. In addition, further feasibility studies are needed to assess the impact of these alterations on the surrounding environment. 


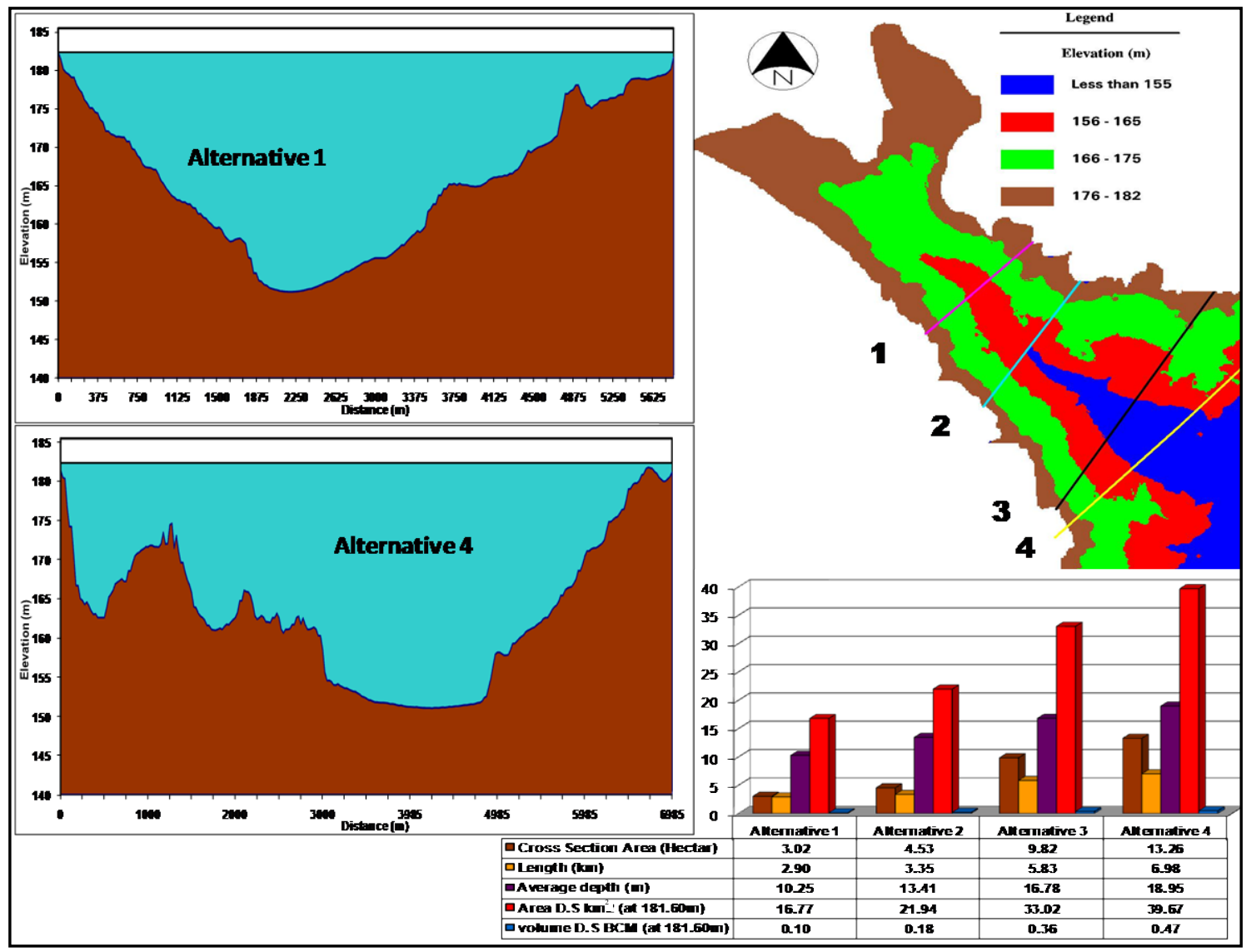

Figure 17. Assessment of the alternatives for eliminating Khor Sara.

Table 4. Expected saved evaporation losses from Lake Nasser due to eliminating Khor Korosko under the current climate conditions and according to the ECHAM5 and HadCM3 climate models.

\begin{tabular}{ccccccccc}
\hline \multirow{2}{*}{ Elevation } & Current climate & \multicolumn{3}{c}{ ECHAM5 } & \multicolumn{3}{c}{ HadCM3 } \\
\cline { 3 - 8 } & & 2030 & 2050 & 2100 & 2030 & 2050 & 2100 \\
\hline 160 & 0.091 & 0.094 & 0.096 & 0.100 & 0.094 & 0.096 & 0.099 \\
165 & 0.124 & 0.127 & 0.130 & 0.135 & 0.127 & 0.129 & 0.134 \\
170 & 0.155 & 0.159 & 0.163 & 0.170 & 0.160 & 0.162 & 0.168 \\
175 & 0.201 & 0.206 & 0.211 & 0.220 & 0.207 & 0.210 & 0.218 \\
180 & 0.288 & 0.295 & 0.302 & 0.315 & 0.296 & 0.301 & 0.312 \\
182 & 0.309 & 0.317 & 0.325 & 0.338 & 0.318 & 0.323 & 0.335 \\
\hline
\end{tabular}

Table 5. Expected saved evaporation losses from Lake Nasser due to eliminating Khor Sara under the current climate conditions and according to the ECHAM5 and HadCM3 climate models.

\begin{tabular}{ccccccccc}
\hline \multirow{2}{*}{ Elevation } & \multirow{2}{*}{ Current climate conditions } & \multicolumn{3}{c}{ ECHAM5 } & \multicolumn{3}{c}{ HadCM3 } \\
\cline { 3 - 8 } & & 2030 & 2050 & 2100 & 2030 & 2050 & 2100 \\
\hline 160 & 0.016 & 0.017 & 0.017 & 0.018 & 0.017 & 0.017 & 0.017 \\
165 & 0.030 & 0.031 & 0.031 & 0.033 & 0.031 & 0.031 & 0.032 \\
170 & 0.052 & 0.053 & 0.055 & 0.057 & 0.054 & 0.054 & 0.056 \\
175 & 0.074 & 0.076 & 0.077 & 0.081 & 0.076 & 0.077 & 0.080 \\
180 & 0.114 & 0.117 & 0.120 & 0.125 & 0.118 & 0.119 & 0.124 \\
182 & 0.119 & 0.122 & 0.125 & 0.130 & 0.123 & 0.124 & 0.129 \\
\hline
\end{tabular}


It is recommended that Khor Kalabsha be cultivated after dam construction. A two kilometer buffer zone must be left between the proposed dams and the agricultural farms within this khor according to decree 203/2002. Moreover, organic fertilizers and alternative types or low amounts of pesticides must be applied to the soils to protect the groundwater reservoir around the lake. Finally, environmental conservation must be considered for the proposed dams design by adding some gates to permit very small water depth flow to the khors to attract the birds, fish, and animals that presently inhabit the area. The detailed design of these dams and their costs are beyond the scope of this paper. The cost of building dams is usually high, but it is low with relative to the cost of increasing water scarcity in Egypt. To decrease the cost, the dams should be constructed using the local lake-deposited material which will lead also to an increase in the lake's storage capacity.

\section{REFERENCES}

[1] M. A. Abu-Zeid, "Water Resources Assessment for Egypt," International Journal of Water Resources Development, Vol. 8, No. 2, 2007, pp. 76-86. http://dx.doi.org/10.1080/07900629208722537

[2] M. Shahin, "Hydrology of the Nile Basin," Elsevier, Amsterdam, 1985.

[3] R. Said, "The River Nile," Geology, Hydrology and Utilization, Pergamon Press, Oxford, 1993.

[4] A. Gupta, "Large Rivers,” Geomorphology and Management, John Wiley, Chichester, 2007.

[5] M. Elsawwaf, P. Willems, A. Pagano and J. Berlamont, "Evaporation Estimates from Nasser Lake, Egypt, Based on Three Floating Station Data and Bowen Ratio Energy Budget,” Theoretical and Applied Climatology, Vol. 100, No. 3, 2010, pp. 439-465. http://dx.doi.org/10.1007/s00704-009-0168-z

[6] J. V. Sutcliffe and Y. P. Parks, "The Hydrology of the Nile,” IAHS Press, UK, 1999.

[7] M. A. Abu-Zeid and F. Z. El-Shibini, "Egypt's High Aswan Dam,” Water Resources Development, Vol. 13, No. 2, 1997, pp. 209-217. http://dx.doi.org/10.1080/07900629749836

[8] M. Elsawwaf, P. Willems and J. Feyen, “Assessment of the Sensitivity and Prediction Uncertainty of Evaporation Models Applied to Nasser Lake, Egypt,” Journal of Hydrology, Vol. 395, No. 1-2, 2010, pp. 10-22. http://dx.doi.org/10.1016/j.jhydrol.2010.10.002

[9] MWRI, "Lake Research Mission Report in Year 2007," Nile Water Sector, Ministry of Water Resources and Irrigation, Egypt, 2007.

[10] A. E. Mynett and Z. Vojinovic, "Hydroinformatics in Multi-Colours-Part Red, Urban Flood and Disaster Management,” Journal of Hydroinformatics, Vol. 11, No. 3-4,
2009, pp. 166-179.

http://dx.doi.org/10.2166/hydro.2009.027

[11] M. E. Elshamy, H. S. Wheater, N. Gedney and C. Huntingford, "Evaluation of the Rainfall Component of a Weather Generator for Climate Impact Studies,” Journal of Hydrology, Vol. 326, No. 1-4, 2006, pp. 1-24. http://dx.doi.org/10.1016/j.jhydrol.2005.09.017

[12] K. M. Strzepek, D. N. Yates and D. E. Elquosy, "Vulnerability Assessment of Water Resources in Egypt to Climatic Change in the Nile Basin," Climate Research Journal, Vol. 6, 1996, pp. 89-95. http://dx.doi.org/10.3354/cr006089

[13] G. A. Meehl, T. F. Stocker, W. D. Collins, P. Friedlingstein, A. T. Gaye, J. M. Gregory, A. Kitoh, R. Knutti, et al., "Global Climate Projections. In: Climate Change 2007: The Physical Science Basis. Contribution of Working Group I to the Fourth Assessment Report of the Intergovernmental Panel on Climate Change," Cambridge University Press, Cambridge, 2007.

[14] LNDFC, "Impact of Climate Change on the Water Supply to Egypt," Lake Nasser Flood and Drought Control Project, Planning Sector, Ministry of Water Resources and Irrigation, Egypt, 2005.

[15] J. Frenkiel, "Evaporation Reduction: Physical and Chemical Principles and Review of Experiments," Arid Zone Research 27, 1965.

http://unesdoc.unesco.org/images/0007/000700/070035eo .pdf

[16] P. Verburg and R. Hecky, "Wind Patterns, Evaporation, and Related Physical Variables in Lake Tanganyika, East Africa: The African Great Lakes,” Journal of Great Lakes Research, Vol. 29, No. 2, 2003, pp. 48-61. http://dx.doi.org/10.1016/S0380-1330(03)70538-3

[17] I. Craig, A. Green, M. Scobie and E. Schmidt, "Controlling Evaporation Loss from Water Storages,” National Centre for Engineering in Agriculture Publication 1000580/ 1, USQ, Toowoomba, 2005.

[18] X. Yao, "Evaporation Reduction by Suspended and Floating Covers: Overview, Modeling and Efficiency,” Urban Water Security Research Alliance, Technical Report No. 28, 2010.

[19] H. M. I. Ebaid and S. S. Ismail, "Lake Nasser Evaporation Reduction Study," Journal of Advanced Research, Vol. 1, No. 4, 2010, pp. 315-322. http://dx.doi.org/10.1016/j.jare.2010.09.002

[20] S. S. Zaghloul, N. Pacini, K. Schwaiger and P. Henry de Villeneuve, "Towards a Lake Nasser Management Plan: Results of a Pilot Test on Integrated Water Resources Management,” Proceedings of the Fifteenth International Water Technology Conference, Alexandria, 2011.

[21] M. Elarabawy and P. Tosswell, "An Appraisal of the Southern Valley Development Project in Egypt,” Journal of Water Supply: Research and Technology-Aqua, Vol. 47, 1998, pp. 167-175. http://dx.doi.org/10.1046/j.1365-2087.1998.00096.x 